\title{
Online Scientific Events: A Post-Pandemic Reality?
}

\author{
Eventos Científicos Online: ¿Una realidad Post-Pandemia?
}

\author{
Wilson Gustavo Cral \& Dagmar de Paula Queluz
}

CRAL, W. C. \& QUELUZ, D. P. Online scientific events: A post-pandemic?. Int. J. Odontostomat., 15(1):1-1, 2021.

The COVID-19 pandemic, declared by the World Health Organization, in March 2020 (World Health Organization, 2020), has demonstrated great flexibility in relation to scientific production. An example of this new reality has been the holding of scientific events, such as symposiums and congresses with a completely online format.

Unlike what happens in the COVID-19 pandemic, most scientific events were held in person. In view of the new conditions and possibilities, the organization of these events is adapting to digital platforms, which in addition to a scientific grid and their own schedule, have online registration systems, certificates of participation and, even, presentations of scientific works by the congressmen.

Among the advantages of online scientific events, we can mention the reduction of physical costs and the minimization of face-to-face geographic distances, which may eventually hinder the access and participation of an audience of interest. Given this, does this new scientific modality tend to remain in a future reality, post-pandemic?

Although medical and dental events value work and face-to-face experience, such as exhibitions in the purchase and sale of new equipment, it is interesting to observe and predict the future of scientific events that develop according to the great potential of the internet (Axiotis \& Benson, 2020).

Online scientific events present great possibilities for changing the post-pandemic world, given the success that this new experience has demonstrated and been reported by different professionals. The improvement of digital platforms for these meetings, the creation of new tools and the dissemination of lectures are promising for the quality and the public's adhesion is increasingly greater, strengthening the relationship between information technology and the different areas of knowledge in today's world.

\section{REFERENCES}

Axiotis, N. \& Benson, L. The future for dental events. Br. Dent. J., 228(11):811, 2020.

World Health Organization (WHO). Report of the WHO-China Joint Mission on coronavirus disease 2019 (COVID-19). Geneva, World Health Organization, 2020. Available from: https:// www.who.int/docs/default-source/coronaviruse/who-china-jointmission-on-covid-19-final-report.pdf

Corresponding author:

Wilson Gustavo Cral

Av. Limeira, 901 - Areião

Piracicaba - SP

13414-903

BRAZIL

E-mail address: wgcral@gmail.com 